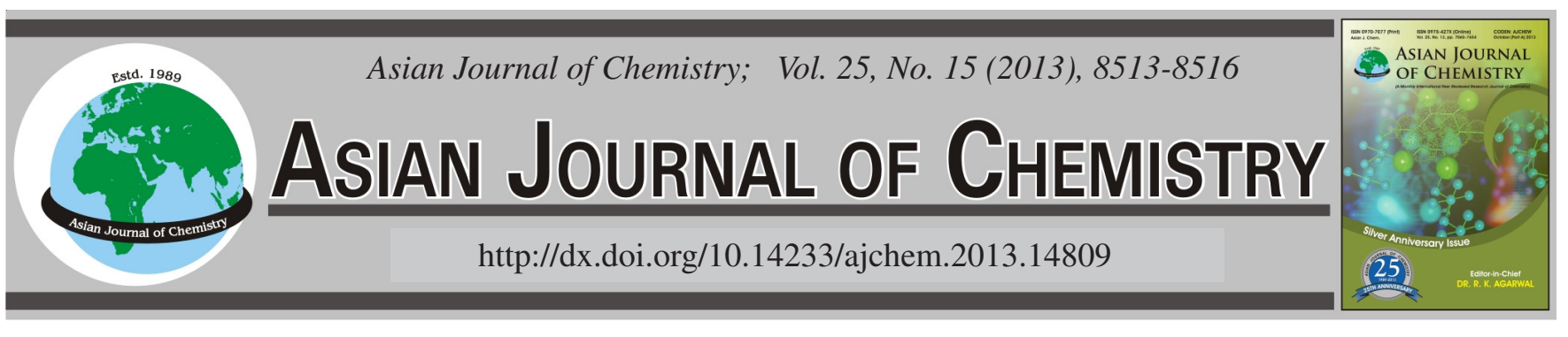

\title{
Dyeing of Silk Fabric with Eco-Friendly Natural Dyes Obtained from Spathodea campanulata and Cordia sebestena: A Comparison
}

\author{
M. Kumaresan ${ }^{1, *}$, P.N. Palanisamy ${ }^{2}$ and P.E. Kumar ${ }^{3}$
}

\begin{abstract}
${ }^{1}$ Department of Chemistry, Erode Sengunthr Engineering College, Perundurai, Erode-638 057, India
${ }^{2}$ Department of Chemistry, Kongu Engineering College Perundurai, Erode-638 052, India

${ }^{3}$ Department of Chemistry, Erode Arts and Science College, Erode-638 009, India

*Corresponding author: E-mail: mkumsrenu@yahoo.com
\end{abstract}

(Received: 10 November 2012;

Accepted: 24 August 2013)

AJC-13985

\begin{abstract}
Bleached silk fabric was dyed with natural dyes obtained from the flower of Spathodea campanulata and Cordia sebestena. The colour fastness properties and colour strength of dyed silk fabric were determined and compared. From the comparative study of fastness properties and colour strength of the dyed cotton samples, Spathodea campanulata in simultaneous mordanting method with $3 \%$ mordant combination gives better results as compared to the natural dye obtained from the flower of Cordia sebestena.

Key Words: Cordia sebestena, Cotton, Fastness, Mordants, Natural dye, Spathodea campanulata.
\end{abstract}

\section{INTRODUCTION}

With the world becoming more conscious towards ecology and environment, there is greater need today to revive the tradition of natural dye and dyeing techniques as an alternative of hazardous synthetic dyes is an extremely crude.

Until about 150 years ago all dyes were natural substances, derived mainly from plants and animals. The natural dyes present in plants and animals are pigmentary molecules ${ }^{1}$ which impart colour to the materials. Recently, interest in the use of natural dyes has been growing rapidly due to the result of stringent environmental standards imposed by many countries in response to toxic and allergic reactions associated with synthetic dyes ${ }^{2}$.

There are several plants/plant parts that provide natural dyes which are used in the textile industry. However, the common drawbacks of natural dyes are their non-reproducible and non-uniform shades, poor to moderate colour fastness and lack of scientific information on the chemistry of dyeing and standardised dyeing methods ${ }^{3}$. Many reports are available on application of natural dyes on cotton ${ }^{4-6}$.

The present investigation deals with the extraction of natural dyes from the flower of Spathodea campanulata and flower of Cordia sebestena grow in all warm and damp parts of India.

The aim of present work has been carried out to prepare eco-friendly natural dyes from the flower of Spathodea campanulata and flower of Cordia sebestena and apply them on silk fabric. In the present work an attempt has been made to study the effect of mordanting and dyeing properties ${ }^{7}$ of silk fabrics such as, washing, rubbing, light fastness and perspiration $^{8}$ and also to visualize the effect of myrobolan and metallic mordants have been undertaken.

\section{EXPERIMENTAL}

Loom state silk (430 ends/dm, 212 picks $/ \mathrm{dm}, 50 \mathrm{~g} / \mathrm{m}^{2}$ ) fabric, obtained from Khadhi Trust, Dindugal, was used for this study. Analytical reagents (AR) grade ferrous sulphate, aluminium sulphate, nickel sulphate, potassium dichromate, stannous chloride, commercial grade acetic acid, common salt, sodium carbonate were used. A natural mordant myrobolan (Terminalia chebula) powder was used for the study. Depending upon the mordant used, the colour obtained on textiles from the flower of Spathodea campanulata and flower of Cordia sebestena extracts may give different shades.

Extraction of colour component: For optimizing ${ }^{9}$ the extraction method the ethanol extraction of dye liquor was carried out under varying conditions, such as time of extraction, temperature of extraction bath and material-to-liquor ratio. In each case, the optical density or absorbance value at a particular maximum absorbance wavelength $\left(\lambda_{420} \mathrm{~nm}\right)$ for the ethanol extract of plant parts were estimated by using Hitachi-U-2000 UV-VIS absorbance spectrometer.

Dyeing of silk fabrics with the extract of flower of Spathodea campanulata and flower of Cordia sebestena: The wetted out silk samples were entered into dye baths containing 
required amount of dye extract and water. After $10 \mathrm{~min}$, required amount of sodium carbonate and sodium chloride were added. The dyeing was carried out for $1 \mathrm{~h}$ at $60{ }^{\circ} \mathrm{C}$. The dyed samples were dried in air without washing to make them ready for pre, simultaneous and post-mordanting using myrobolan and metallic salts.

Pre-mordanting of cotton fabric with myrobolan and metallic salts: Bleached cotton fabric with or without premordanting were further mordanted prior to dyeing using 1$3 \%$ of any one of the chemical mordants, such as aluminium sulphate, nickel sulphate, potassium dichromate, stannous chloride, copper sulphate and the myrobolan, at $60^{\circ} \mathrm{C}$ for $0.5 \mathrm{~h}$ with material-to-liquor ratio of 1:20. The samples treated with metal salts were dyed with the dye extract.

Simultaneous mordanting of silk fabrics with myrobolan and metallic salts: Bleached silk fabrics were treated with both dye extract and metal salts simultaneously, using 1-3\% of any one of the chemical mordants, such as aluminium sulphate, nickel sulphate, potassium dichromate, stannous chloride, copper sulphate and the myrobolan, at $60{ }^{\circ} \mathrm{C}$ for 0.5 $\mathrm{h}$ with material-to-liquor ratio of 1:20.

Post-mordanting of silk fabrics with myrobolan and metallic salts: Bleached silk fabrics were dyed with dye extract. The wetted out silk samples were entered into different dye baths containing required amount of dye extract and water. After 10 min required amount of sodium sulphate was added. After 20 min required amount of sodium chloride was added. The dyeing was carried out for $1 \mathrm{~h}$ at $50^{\circ} \mathrm{C}$. The dyed samples were taken out, squeezed and used for treatment with metal salts process without washing. The dyed silk samples were treated with different metal salts using 1-3\% of any one of the chemical mordants, such as aluminium sulphate, nickel sulphate, potassium dichromate, stannous chloride, copper sulphate and the myrobolan, at $60{ }^{\circ} \mathrm{C}$ for $0.5 \mathrm{~h}$ with material-to-liquor ratio of $1: 20$.

In all the above three methods, after the dyeing is over, the dyed samples were repeatedly washed with water and then dried in air. Finally, the dyed samples were subjected to soaping with $2 \mathrm{gpl}$ soap solution at $50{ }^{\circ} \mathrm{C}$ for $10 \mathrm{~min}$, followed by repeated water wash and drying under sun.

Determination of surface colour strength (K/S value): The K/S value of the undyed and dyed cotton fabrics was determined ${ }^{10}$ by measuring surface reflectance of the samples using a computer-aided Macbeth 2020 plus reflectance spectrophotometer, using the following Kubelka Munk equation with the help of relevant software:

$$
\frac{\mathrm{K}}{\mathrm{S}}=\frac{\left(1-\mathrm{R}_{\lambda_{\max }}\right)^{2}}{2 \mathrm{R}_{\lambda_{\max }}}=\alpha \mathrm{Cd}
$$

where $\mathrm{K}$ is the coefficient of absorption; $\mathrm{S}$ the coefficient of scattering; Cd, the concentration of the hue and $\mathrm{R}_{\lambda_{\max }}$ the surface reflectance value of the sample at a particular wavelength, where maximum absorption occurs for a particular dye/colour component.

Evaluation of colour fastness: Colour fastness to washing of the dyed fabric samples was determined as per IS: 7641984 method using a Sasmira launder-O-meter following Is-3 wash fastness method. The wash fastness rating was assessed using grey scale as per ISO-05-A02 (loss of shade depth) and
ISO-105-AO3 (extent of staining) and the same was crosschecked by measuring the loss of depth of colour and staining using Macbeth 2020 plus computer-aided colour measurement system attached with relevant software. Colour fastness to rubbing (dry and wet) was assessed as per IS: 766-1984 method using a manually operated crock meter and grey scale as per ISO-105-AO3 (extent of staining).

Colour fastness to exposure to light was determined as per IS: 2454-1984 method. The sample was exposed to UV light in a Shirley MBTF Microsal fade-O-meter (having 500 watt Philips mercury bulb tungsten filament lamp simulating day light) along with the eight blue wool standards (BS 1006: BOI: 1978). The fading of each sample was observed against the fading of blue wool standards (1-8).

Colour fastness to perspiration assessed according to IS 971-1983 composite specimen was prepared by placing the test specimen between two adjacent pieces of fabrics of silk and stitched all among four sides. The sample was soaked in the test solution (acidic /alkaline) separately with MLR 1:50 for $0.5 \mathrm{~h}$ at room temperature. The sample was then placed between two glass plates of perspirometer under load of 4.5 $\mathrm{kgs}(10 \mathrm{lbs})$. The apparatus was kept in the oven for $4 \mathrm{~h}$ at 37 $\pm 2{ }^{\circ} \mathrm{C}$. At the end of this period the specimen was removed and dried in air at a temperature not exceeding $60{ }^{\circ} \mathrm{C}$. The test samples were graded for change in colour and staining using grey scales.

\section{RESULTS AND DISCUSSION}

The colour strength values of silk fabrics dyed with the natural dyes obtained from the flower of Spathodea campanulata and flower of Cordia sebestena by using single mordanting method are presented and compared in Tables 1-3.

From the results, it was observed that among the two plant parts, Spathodea campanulata showed better colour strength values. In all the three dyeing methods, simultaneous method gave excellent results. In all the three methods of dyeing, using two plant parts, the mordants ferrous sulphate and aluminium sulphate show excellent colour strength values. For dyeing of silk, 1, 2 and $3 \%$ mordant concentrations were used for the present study. Among these three concentrations $3 \%$ mordant concentration gave better results.

The colour fastness values of silk fabrics dyed with the flower of Spathodea campanulata and flower of Cordia sebestena obtained in this study by using single mordanting method are presented and compared in Table-4.

From the results, it was observed that among the two plant parts, Spathodea campanulata showed better light fastness properties. Similar rub fastness and perspiration fastness values were obtained. Spathodea campanulata showed better wash fastness when compared with Cordia sebestena dyed silk fabrics.

In all the three dyeing methods, simultaneous method gave excellent results. In all the three methods of dyeing, using two plant parts, the mordants ferrous sulphate and aluminium sulphate show excellent results. Among the three concentrations $3 \%$ mordant concentration gave better fastness results.

Similar results were obtained in the previous study reported by Das et al. ${ }^{12}$. The present study shows excellent wash fastness (GS:4) and light fastness (GS:4) when compared 


\begin{tabular}{|c|c|c|c|c|c|c|}
\hline \multicolumn{7}{|c|}{$\begin{array}{c}\text { TABLE-1 } \\
\text { SURFACE COLOUR STRENGTH OF Spathodea campanulata }(\text { SC) AND Cordia sebestena }(\mathrm{CS}) \text { DYED SILK FABRIC } \\
\text { AFTER PRE, SIMULTANEOUS AND POST MORDANTING METHODS BY USING } 1 \% \text { MORDANT } \\
\text { CONCENTRATION. K/S VALUE WITHOUT MORDANT: SILK-2.41 (SC), } 2.37 \text { (CS) }\end{array}$} \\
\hline \multirow{3}{*}{$\begin{array}{l}\text { Mordant concentration: } \\
\qquad(1 \%)\end{array}$} & \multicolumn{6}{|c|}{$\mathrm{K} / \mathrm{S}(\lambda=420 \mathrm{~nm})$} \\
\hline & \multicolumn{2}{|c|}{ Pre-mordanting } & \multicolumn{2}{|c|}{ Simultaneous mordanting } & \multicolumn{2}{|c|}{ Post mordanting } \\
\hline & $\mathrm{SC}$ & $\mathrm{CS}$ & $\mathrm{SC}$ & $\mathrm{CS}$ & $\mathrm{SC}$ & $\mathrm{CS}$ \\
\hline Nickel sulphate & 2.21 & 2.27 & $2.51,2.51$ & 2.59 & 2.42 & 2.32 \\
\hline Aluminium sulphate & 2.48 & 2.38 & 2.78 & 2.66 & 2.56 & 2.49 \\
\hline Potassium dichromate & 1.94 & 1.45 & 2.21 & 1.91 & 2.14 & 1.72 \\
\hline Ferrous sulphate & 2.54 & 2.48 & 2.83 & 2.70 & 2.69 & 2.54 \\
\hline Stannous chloride & 2.44 & 2.32 & 2.70 & 2.57 & 2.59 & 2.44 \\
\hline Myrobolan & 1.91 & 1.33 & 2.25 & 2.12 & 2.12 & 2.00 \\
\hline
\end{tabular}

\begin{tabular}{|c|c|c|c|c|c|c|}
\hline \multicolumn{7}{|c|}{$\begin{array}{c}\text { TABLE-2 } \\
\text { SURFACE COLOUR STRENGTH OF Spathodea campanulata (SC) AND Cordia sebestena (CS) DYED SILK } \\
\text { FABRIC AFTER PRE,SIMULTANEOUS AND POST MORDANTING METHODS BY USING 2\% } \\
\text { MORDANT CONCENTRATION. K/S VALUE WITHOUT MORDANT: SILK-2.41 (SC), } 2.37 \text { (CS) }\end{array}$} \\
\hline \multirow{3}{*}{$\begin{array}{c}\text { Mordant concentration: } \\
(2 \%)\end{array}$} & \multicolumn{6}{|c|}{$\mathrm{K} / \mathrm{S}(\lambda=420 \mathrm{~nm})$} \\
\hline & \multicolumn{2}{|c|}{ Pre-mordanting } & \multicolumn{2}{|c|}{ Simultaneous mordanting } & \multicolumn{2}{|c|}{ Post mordanting } \\
\hline & $\mathrm{SC}$ & $\mathrm{CS}$ & $\mathrm{SC}$ & $\mathrm{CS}$ & $\mathrm{SC}$ & CS \\
\hline Nickel sulphate & 2.31 & 2.37 & 2.62 & 2.69 & 2.53 & 2.39 \\
\hline Aluminium sulphate & 2.59 & 2.38 & 2.87 & 2.75 & 2.61 & 2.51 \\
\hline Potassium dichromate & 1.95 & 1.39 & 2.29 & 2.09 & 2.18 & 1.88 \\
\hline Ferrous sulphate & 2.63 & 2.59 & 2.94 & 2.81 & 2.74 & 2.67 \\
\hline Stannous chloride & 2.50 & 2.41 & 2.72 & 2.63 & 2.63 & 2.53 \\
\hline Myrobolan & 1.81 & 1.39 & 2.21 & 2.23 & 2.15 & 2.14 \\
\hline
\end{tabular}

\begin{tabular}{|c|c|c|c|c|c|c|}
\hline \multicolumn{7}{|c|}{$\begin{array}{l}\text { TABLE-3 } \\
\text { SURFACE COLOUR STRENGTH OF Spathodea campanulata (SC) AND Cordia sebestena }(\mathrm{CS}) \text { DYED SILK } \\
\text { FABRIC AFTER PRE, SIMULTANEOUS AND POST MORDANTING METHODS BY USING } 3 \% \text { MORDANT } \\
\text { CONCENTRATION. K/S VALUE WITHOUT MORDANT: SILK-2.41(SC), } 2.37(\mathrm{CS})\end{array}$} \\
\hline \multirow{3}{*}{$\begin{array}{c}\text { Mordant concentration: } \\
\qquad(3 \%)\end{array}$} & \multicolumn{6}{|c|}{$\mathrm{K} / \mathrm{S}(\lambda=420 \mathrm{~nm})$} \\
\hline & \multicolumn{2}{|c|}{ Pre-mordanting } & \multicolumn{2}{|c|}{ Simultaneous mordanting } & \multicolumn{2}{|c|}{ Post mordanting } \\
\hline & SC & $\mathrm{CS}$ & SC & $\mathrm{CS}$ & $\mathrm{SC}$ & $\mathrm{CS}$ \\
\hline Nickel sulphate & 2.26 & 2.39 & 2.62 & 2.65 & 2.51 & 2.36 \\
\hline Aluminium sulphate & 2.58 & 2.51 & 2.89 & 2.79 & 2.67 & 2.55 \\
\hline Potassium dichromate & 2.01 & 1.33 & 2.35 & 1.98 & 2.24 & 1.73 \\
\hline Ferrous sulphate & 2.63 & 2.58 & 2.95 & 2.81 & 2.76 & 2.67 \\
\hline Stannous chloride & 2.53 & 2.41 & 2.76 & 2.66 & 2.67 & 2.51 \\
\hline Myrobolan & 1.78 & 1.43 & 2.21 & 2.32 & 2.19 & 2.19 \\
\hline
\end{tabular}

TABLE-4

COMPARISON OF FASTNESS PROPERTIES AND COLOUR STRENGTH OF DYED SILK USING SINGLE MORDANTS

\begin{tabular}{|c|c|c|c|c|c|c|c|c|c|}
\hline \multirow{3}{*}{$\begin{array}{l}\text { Plant parts used } \\
\text { for dyeing }\end{array}$} & \multirow{3}{*}{ Mordant used } & \multirow{3}{*}{ Method } & \multicolumn{6}{|c|}{ Properties } & \multirow{3}{*}{ Reference } \\
\hline & & & \multirow{2}{*}{ WF } & \multirow{2}{*}{ LF } & \multicolumn{2}{|c|}{$\mathrm{RF}$} & \multicolumn{2}{|c|}{$\mathrm{PF}$} & \\
\hline & & & & & Dry & Wet & Acidic & Alkaline & \\
\hline \multirow{4}{*}{$\begin{array}{c}\text { Stem of Achras } \\
\text { sapota }\end{array}$} & Ferrous sulphate (3\%) & SM & 5 & 5 & 5 & 5 & 4 & 4 & \multirow{8}{*}{ Present study } \\
\hline & & PM & 4 & 4 & 5 & 5 & 5 & 5 & \\
\hline & Aluminium sulphate (3\%) & SM & 4 & 4 & 5 & 5 & 4 & 4 & \\
\hline & & PM & 5 & 4 & 5 & 5 & 5 & 5 & \\
\hline \multirow{4}{*}{$\begin{array}{l}\text { Flower of Spathodea } \\
\text { campanulata }\end{array}$} & Ferrous sulphate (3\%) & SM & 5 & 5 & 5 & 4 & 5 & 5 & \\
\hline & & PM & 5 & 4 & 5 & 5 & 5 & 5 & \\
\hline & Aluminium sulphate ( $3 \%$ ) & SM & 4 & 5 & 5 & 4 & 4 & 4 & \\
\hline & & $\mathrm{PM}$ & 4 & 4 & 5 & 5 & 5 & 5 & \\
\hline Eclipta prostata & Ferrous sulphate $(3 \%)$ & $\mathrm{PM}$ & 5 & 8 & 5 & 5 & 5 & 5 & Sharada devi et al. ${ }^{11}$ \\
\hline \multirow{2}{*}{ Rheum emodi } & Aluminium sulphate (3\%) & SM & 4 & 3 & - & - & - & - & \multirow{2}{*}{ Das et al. ${ }^{12}$} \\
\hline & Ferrous sulphate (3\%) & SM & 4 & 3 & - & - & - & - & \\
\hline \multirow{2}{*}{ Bixa orellana } & Aluminium sulphate (3\%) & PM & $3-4$ & 4 & - & - & - & - & \multirow{2}{*}{ Das et al. ${ }^{13}$} \\
\hline & Ferrous sulphate (3\%) & PM & $2-3$ & 3 & - & - & - & - & \\
\hline
\end{tabular}

WF-Wash fastness LF-Light fastness PF-Perspiration fastness RF-Rub fastness CS-Colour strength PM-Pre mordanting SM-Simultaneous mordanting. 
with Das et al. ${ }^{13}$ study (WF:2-3 and LF:3). A better light fastness (GS:8) was reported by Sharada devi et al. ${ }^{11}$ in pre mordanting method.

\section{Conclusion}

From the comparative study of fastness properties and colour strength of the dyed silk samples, Spathodea campanulata in simultaneous mordanting method with $3 \%$ mordant combination gives better results as compared to the Achras sapota dye.

\section{ACKNOWLEDGEMENTS}

The authors are thankful to Mr. P. Santharaj, Department of Textile Processing, Erode Institute of Technology for his support in the analysis of fastness properties of the dyed samples of this work.

\section{REFERENCES}

1. S. Bains, O.P. Singh, G. Goraya and M. Kang, J. Textile Assoc., 183 (2003).

2. K. Anitha and S.N. Prasad, Curr. Sci., 92, 1681 (2007).
3. M.L. Gulrajani and D. Gupta, Natural Dye and their Application to Textiles, p. 25 (1992)

4. B. Anderson, Creative Spinning, Weaving and Plant Dyeing, Angus and Robinson, Singapore, 24-28 (1971)

5. S. Adeel, S. Ali, I.A. Bhatti and F. Zsila, Asian J. Chem., 21, 3493 (2009).

6. M. Kumaresan and P.N. Palanisamy, Int. J. Appl. Eng. Res., 5, 2031 (2010).

7. R.R. Mahangade, P.V. Varadarajan, J.K. Verma and H. Bosco, Indian J. Fibre Textile Res., 34, 279 (2009).

8. H. Goodarzian and E. Ekrami, World Appl. Sci. J., 8, 1387 (2010).

9. P.S. Vankar, R. Shankar and D. Mahanta, Asian Dyer, 51 (2010).

10. M. Kumaresan, P.N. Palanisamy and P.E. Kumar, J. Basic Appl. Scient. Res., 1, 933 (2011).

11. A. Sharada Devi, B.S. Sumanthy and V.K.L.T. Katyayini, Man Made Textiles India, 181 (2002).

12. D. Das, S.R. Maulik and S.C. Bhattacharya, Indian J. Fibre Textile Res., 33, 163 (2008).

13. D. Das, S.R. Maulik and S.C. Bhattacharya, Indian J. Fibre Textile Res., 32, 366 (2007). 